University for Business and Technology in Kosovo

UBT Knowledge Center

UBT International Conference

2014 UBT International Conference

Nov 8th, 2:00 PM - 2:15 PM

\title{
Youth Development in Albania
}

Armanda Keqi

Epoka University, akeqi@epoka.edu.al

Bora Kokalari

Epoka University

Sabina Beqiri

Epoka University

Follow this and additional works at: https://knowledgecenter.ubt-uni.net/conference

Part of the Business Commons

\section{Recommended Citation}

Keqi, Armanda; Kokalari, Bora; and Beqiri, Sabina, "Youth Development in Albania" (2014). UBT International Conference. 34.

https://knowledgecenter.ubt-uni.net/conference/2014/all-events/34

This Event is brought to you for free and open access by the Publication and Journals at UBT Knowledge Center. It has been accepted for inclusion in UBT International Conference by an authorized administrator of UBT Knowledge Center. For more information, please contact knowledge.center@ubt-uni.net. 


\title{
Youth Development in Albania
}

\author{
Armanda Keqi ${ }^{1,}$ Bora Kokalari $^{2,}$, Sabina Beqiri ${ }^{3}$ \\ 1,2,3 Epoka University
}

\begin{abstract}
Young generations are those who make lives livelier and happier, who design the future and make the change, the ones with full hope and enthusiasm to go further and make the impossible possible. As every country of Europe, Asia or America, Albania as well is surrounded by a very fruitful young ladies and gentlemen's. This paper aims to analyse the changes of the youth development in Albania during the transition period. The young development in Albania has faced many problems, such asthe difference between the levels of development of the youths that live in the other cities of Albania with the ones of the capital. Rural areas and small towns are closed where a portion of youth in minor are totally dependent from family, and they are exactly that with their weak hands are inclined to do the heavy work to keep their family one more day alive. Youth at the opening of the borders, generally tended to leave towards legal immigration either as tourist or in illegal opportunities addressing major countries like Britain, Greece, Italy, Belgium etc.Albania needs to make arrangements which will be financed by businessmen, private universities in cooperation with the state to offer young people opportunities to work together and to be closer to each other and to show their skills in conversation competitions. At the same time the state has other open universities in backward areas which will provide young entrepreneurs' with more opportunities for young people to graduate and to serve different areas. Meanwhile, there is needed a strategy to separate the fields in which there is a need to have more expert in the field which is required to work also which would come more to help the country's economy with the addition of experts. Albania is a country blessed where high mountains finish in seas, where groundwater resources are numerous, and with a conductive climate to produce almost all kinds of fruits and where vegetation is very diverse. If the youth will be directed towards learning of foreign languages and in recognition of their territories, traditions and customs, thus, we would make a big step because tourism market is precisely the kind of market where young people will find themselves more comfortable than ever, where the labour force will be insufficient paid and where the demand for products would be required as the number of tourists would be great and just the requirements would change in terms of application areas during the summer as it would be for beaches and seasonal fruits, while during the winter for skiing and mountain tourism.
\end{abstract}

Keywords: Albania, youth development, education, strategy, state, society, blood feud

\section{Introduction}

Albania is a small democratic country located in the South-Eastern Europe. By this time our country has become a strong member of UN, NATO, and The Organization for Security and Co-operation in Europe, Council of Europe and World Trade Organization. Even though Albania has gone through a lot of difficulties through its history, it has made to become this powerful state which is now days. All of this led by the youth force to dominate the new era of development. It takes time to put things back in the belonging place and the same happened with Albanian youth in the transition period. That was the most problematic period of youngster since the development of a country is always expected from the upcoming generations. Youth development was the only key to have a new powerful democratic country. But this development was not the same in every city if Albania. Youth development should include the vast majority of youngsters throughout the Albanian territory not only youngsters in the most developed cities. In our country this must be considered as one of the most significant problems of the time since the future of our nation is based on how we manage ourselves with respect to education and social welfare. The importance of this topic can only be understood by taking the right measures to prevent the unequal development in different parts of the country. Young people in Albania are divided into several classifications. If you can qualify as such, they are classified as: young people who are in the capital, in suburban towns near the capital city and young people who live in remote 
areas as small towns and villages. The Albanian capital city, Tirana generally consists of young people who come from the small towns and villages in order to have a better education near the capital this including better living conditions and education from the most qualified professors. The other cities have the possibility to cooperate and have schools as well but in a less developed way, and this is seen in different aspects, mainly when younger people coming from these cities have to face the habitants of the capital city. Still the importance stands still in the general aim of this paper.

\section{Blood feud}

\subsection{What id blood feud?}

Young people are the new leaders of a country. As such they need a special attention because they are the key to development. Unfortunately, Albania is still a black mark regarding a phenomenon which is inherited from generation to generation called blood feud. Blood feud started with Kanun of Leke Dukagjini. Kanun is a set of moral rules, a code of conduct that once was considered as a formal constitution. The basic principle of Kanun is preserving your honour. Some of its rules have even been included to current Albanian constitution. On the other hand, there is a need of special laws just to prevent some of Kanun rules. The problem with blood feuds today is that people are using their own personal interpretation of the Kanun to suit their needs. They are abusing the laws instead of following the original script, and this is why you see young people becoming targets.

In Albania, the blood feud has returned in rural areas after more than 40 years of being abolished by Albanian communists led by Enver Hoxha. More than 5,500 Albanian families are currently engaged in blood feuds. Blood feud has a simple logic, an eye for an eye. With that being said, if a man of a family is killed his family must take revenge by killing a man of the murderer's family. Albania's blood feuds are carried on through generations. Traditionally only men could be targeted in the vendettas, and only they could exact revenge. The Kanun states - among other things - that the blood of the victim can only be avenged with the blood of the killer. But the code is loosely interpreted these days, and nobody is safe.

\subsection{Causes}

Book Eight of the Kanun, entitled "Honor" addresses the topics of personal honour, social honour and blood and kinship (Kanuni 1989, 130-186). In particular, Article 601 of Chapter 17 of the Kanun states that a man is dishonoured in the following situations:

1. If someone calls him a liar in front of a group of men;

2. If someone spits at him, threatens him, pushes him, or strikes him;

3. If someone reneges on his promise of mediation or on his pledged word;

4. If his wife is insulted or she runs off with someone;

5. If someone takes the weapons he carries on his shoulder or in his belt;

6. If someone violates his hospitality, insulting his friend or his worker;

7. If someone breaks into his house, his sheepfold, his silo, or his milk-shed in his Courtyard;

8. If someone does not repay a debt or obligation;

9. If someone removes the cover of a cooking pot in his hearth;

10. If someone dips a morsel of food before the guest, the guest is dishonoured;

\subsection{Consequences of blood feud}

This phenomenon has a tremendous impact in the children living in the pectin of mourning the absence of their basic rights. They have no single ray of hope that one day they will be free and not within the "prison" that their family has built for them to live in. These children are forced to live isolated in order to actually live. They cannot have a proper education, a normal way of living. Even if they manage to go to school, no one wants a friend that is involved in blood feud. They don't even own shoes; a pointless luxury since they can get by indoors with knitted booties. There are now more than 20,000 
men and boys who live under an ever-present death sentence because of blood feuds. Since 1992, at least 10,000 Albanians have been killed. All these bright minds have anything else but a bright future ahead, all the potential hidden in these kids is going to waste, and the biggest problem is that the government is not taking any exact measures to ban this phenomenon.

\subsection{Solution}

The phenomenon of blood feud, revenge and its consequences in our country exists and as a Consequence of this, the right to life and other human rights and fundamental freedoms are Violated. Although it is a localized phenomenon in some areas of the country and with limited expansion, it remains a concern and therefore deserves to be considered seriously, both politically and socially. State bodies have not yet been able to make proper assessment of this situation, neither start to develop a close collaboration with each other. This is shown by the fact that there are no accurate statistics.

1. The government should seriously evaluate the phenomenon of blood feud and strengthen the cooperation with non-governmental organizations in order to prevent blood feud or revenge.

2. State Police authorities have to undertake measures in order to prevent conflicts, to detect, capture and delivery of all responsible individuals to prosecution bodies, by strengthening as well the cooperation with Interpol to extradite murderers hiding overseas.

3. The Ministry of Education and Science should play a major positive role in order to improve preventive educational programs, so it is ensured the education of the young generation in the spirit of tolerance, against self-justice, blood feud or revenge, and for the treatment of teachers in the areas where blood feud is present in order to assist confined students.

4. Social problems of confined families require a stronger commitment of the state, especially of the Ministry of Labour, Social Affairs and Equal Opportunities, through the regional offices, in order to assist confined families having a low income, as well as to reduce poverty and unemployment.

5. Prosecution bodies should better cooperate with police authorities and conduct prompt investigations, thorough and objective, sending cases for trial with complete and irrefutable evidence. It is not sufficient just to detect and capture offenders, but also their collaborators, organizers, facilitators and associates.

6. The courts have the obligation to quickly and objectively judge and give right sanctions for any offender. Any mild punishment or acquittal unfounded opens the door to self-justice, blood feud and revenge.

If the strength of my words would be exactly what would bring a revolution then I'm going to work for it every second of my life to come to the aid of every teenager's and every baby. Albania needs to state law enforcement tones, which will make possible the freedom of hundreds of young children as mountain winds, as the adult birds full of joy brought to flight. Change is hard, but the difficulties are precisely those that make us stronger.

\section{Inequality between youngsters}

3.1 Illiteracy and educational attainment

According to census results only $2 \%$ of Albanian citizens are illiterate, however this percentage is unevenly distributed. The inequality between rural and urban areas has faded these past year; nevertheless urban areas have a slight priority regarding education. The number of pupils that attend middle school is higher in rural areas in concern to urban ones, respectively $5,7 \%$ and $3,5 \%$. But this percentage changes when we take into consideration high school and university graduated. Only 11.9 
from 100 youngster graduate from high school in rural areas where there is a higher percentage of 29.7 in urban areas. Only $1.1 \%$ of youngsters living in rural areas attend university comparing to $8.9 \%$ in urban ones. There is also a slight change between different parts of Albania. The lowest percentage of illiteracy is in Tirana and the highest in the Northern part of the country, mainly because of unfavourable geographic conditions.

\subsection{The ability to attend school}

In most transition economies, where the labour market is not sustainable, temporary and seasonal employment is relatively high. This type of employment requires workers to be available whenever a work place is presented. An out ways to satisfy the requirements for this type of employment in some European countries East has been the employment of school age people. In some other societies this binding has come as a result of high levels poverty. If the population of school age is involved in this type of employment, school attendance will be affected as a direct consequence. Albania has all the prerequisites to this kind of employment, because ithas a high poverty level and market-wing work is not sustainable at all.

The percentage of people who do not follow middle school is higher urban areas. This pattern is difficult to explain. However, an explanatory reason for this model can be, that the opportunities to find permanent or temporary jobs in urban areas are higher than in rural areas. Bearing in mind that, other results show a locally different model in which school non-attendance is predominantly rural phenomenon and it mostly indicates primary education. The vast majority of people who don't go to school are men, mainly because of economic reasons.

\subsection{Main reasons of non-attendance in rural areas}

1. They have lost interest of school

2. Agriculture work

3. Another full time work

4. Marriage

As it is seen, youngsters abandon school mainly because of economic factors. Since in rural areas the living conditions are worse than in urban areas young people have to work to earn their living. There is clear lack of extra curricular activities in these schools so pupils loose interest of school. Living in rural areas, school can sometimes be seen as a waste of time since there are a lot of other things to do starting from agriculture work to producing dairy products. Their life is constructed in such way that this kind of "business" is inherited, meaning that they don't need a university degree to plant a tree. This is one of the worst mistakes of these people's intellect.

\section{Solution}

If I would have the proper strength to bring this change, than I would implement a strategy, which would come to help to all the youngsters but not only. I would have a strategy that most probably would bring a change. A group of lecturers funded by the state but also with the desire to be helpful to the society in general, at the same time all the students who are part of the teaching branches, nursery services, engineering, social sciences, political sciences etc. All university students with the obligation to have experience in the provision of learning prior to their academic cycle, and in collaboration with persons who do not have the economic means to be part of the school, but also people with disabilities. This would be a push for young people that have not yet economic stability, (that can accomplish it throughout their education) from looking at how far they can reach with their education, but also young people who have reached here to be more aware and not to hesitate to be alongside people in need.

The human ego has had a huge impact on today's society making us literally egocentric. In order for the society to develop everyone should contribute not only financially, but in every way we can. Exchanging experiences is one of the most effective ways of helping people that deal with children education. 
Will help them to become graduated and serve in different areas, but without forgetting that within the university there must be such a policy to protect the graduates, making surveys and statistics so that the diploma is adequate for the students' skills. It is heart-breaking knowing that agriculture studies are the most underrated majors. It's true that agriculture is one of the most risky businesses, but then again the government isn't taking any measures to prevent the falling of its importance. The government should give scholarships for students that choose this kind of major or even give soft loans for every existing farmer, or anyone that is thinking this kind of business. Unfortunately, the number of tourism experts is very low. There is also a lack of quality schools in this field. Albania, located near Mediterrian Sea, is a very beautiful place. It has the ability of all three kinds of tourism, but it lacks qualified people. Tourism is that kind of business that has permanent incomes, but very few people are aware of this here in Albania.

Albania and the state

Addressing youth in vocational schools would be another important step after getting an apprenticeship. It would be a much better management of the separate field supervised by the specialized people instead of creating a huge chaos where no one is responsible of their actions. The specialization in their fields will increase the efficiency, the employment and then will increase the quality of the products.

The state should reduce the living costs of the students with low incomes or to offer them jobs (if for the private business is difficult to pay the salaries than the state should put a part of the money as well) as soon as they get the proper qualification. This would bring a greater demand for study, but also simultaneously help the business recruit new gifted employees with a small economic cost until they becomes experts of that field, the state will reduce the level of unemployment and help in the education of the youth graduating. Students also will be part of the development of the country's institutions and society. In this way many students would focus on graduating with honour degree, rather than thinking of a job because they would be more competitive in the labour market. The business hunger would never fade, at least for the field experts who can make revolutions by taking book lessons into practice. Private universities

State being the main regulator in the functioning of not only the educational system but also in all other areas it will force the universities to turn their attention to the smaller cities with a qualified staff but with a limited number of branches which are generally seen as necessary for other cities and rural areas. This will make a greater distribution and a lower cost because students can study and also work at the same time, because it is easier to work being close to both work and study. Private universities should have lower economical prices if necessary the state should help these universities with the fiscal barriers. This is one of the most flexible fields, starting from investing in pedagogues to private universities. Many students that have special abilities in certain fields are left undiscovered because of economic factors. Their families cannot afford taking these children to universities that really would take care of their skills.

\section{Conclusion}

Throughout this paper I have claimed the state to be the main factor but simultaneously be supported by private institution if it is unable to meet the burden that could have. I'm convinced that even if the state would reach for a partner to private institutions they will show willingness to work together, because state is the trust worthiest partner for private businesses since it can never go bankrupted. Let us hope that the state take up the role that belongs to it and be the one to put some of the proposals I have mentioned above into practice, thoughts which could become a reality and bring an increasing interest in young intellectuals for a rapid change of the countries situation. All this can help in creating the image of a strong and solid state that function well in its entirety as a system. This would lead to a social mobility, bringing the lower classes closer to the higher ones.

To sum up Albania in the future will become a part of the competitive countries in Europe and hopefully spread its roots worldwide. Only knowledge can bring the power of global competitiveness. 


\section{References}

1) USA Today news report, (March 2013), Albanian blood feud kids must hide or risk lives. Available at: http://www.usatoday.com/story/news/world/2013/03/02/albanian-bloodfeud-families/1958503/

2) Environmental Center, (December 2001) , Bujqesia ekologjike Available at: http://kos.rec.org/albanian/pdf/Bujqesia\%20Ekologjike.pdf

3) INSTAT, Varferia ne Shqiperi Available at: http://www.instat.gov.al/media/169434/varferia_ne_shqiperi.pdf

4) Immigration and Refugee Board of Canada, (May 2008), Issue Paper ALBANIA BLOOD FEUDS Available at: https://www.facebook.com/l.php?u=https\%3A\%2F\%2Fwww.ecoi.net\%2Ffile_upload\%2F16 84_1243258524_http-www2-irb-cisr-gc-ca-en-research-publications-index-ehtm.pdf\&h=bAQEL9-HM

5) Mortimer M., \& Toader A., News report, Blood feuds blight Albanian lives Available at: http://news.bbc.co.uk/2/hi/europe/4273020.stm

6) Cohen N., (2010), News report, Blood feuds still boiling in Albania, Available at: http://usatoday30.usatoday.com/news/world/story/2012-07-29/albania-bloodfeuds/56580022/1

7) Gjonluli A., (2013) ,Child victims of Albania's blood feuds, Available at: http://www.news.com.au/world/child-victims-of-albanias-blood-feuds/story-fndir2ev1226733879986 